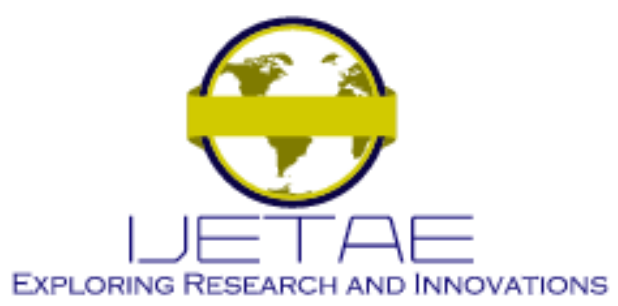

International Journal of Emerging Technology and Advanced Engineering

Website: www.ijetae.com (E-ISSN 2250-2459, Scopus Indexed, ISO 9001:2008 Certified Journal, Volume 11, Issue 08, August 2021)

Manuscript Received: 05 July 2021, Received in Revised form: 07 August 2021, Accepted: 14 August 2021

DOI: 10.46338/ijetae0821_04

\title{
The Development of the Method of Radar Observation System Construction of the Airspace on the Basis of Genetic Algorithm
}

\author{
Oleksandr Oleksenko ${ }^{1}$, Hennadii Khudov ${ }^{2}$, Kyrylo Petrenko $^{3}$, Yurii Horobets ${ }^{4}$, Valerii Kolianda ${ }^{5}$, Nina Kuchuk ${ }^{6}$, \\ Andrij Konstantinov $^{7}$, Volodymyr Kireienko ${ }^{8}$, Oleksii Serdiuk ${ }^{9}$, Iryna Yuzova ${ }^{10}$, Yuriy Solomonenko ${ }^{11}$ \\ 1,2,7,9,10,11 Ivan Kozhedub Kharkiv National Air Force University, Ukraine, Kharkiv, 61023 \\ ${ }^{3,4,8}$ National Defense University of Ukraine named after Ivan Cherniakhovskyi, Ukraine, Kyiv, 01001 \\ ${ }^{5}$ National Academy of the National Guard of Ukraine, Ukraine, Kharkiv, 61001 \\ ${ }^{6}$ National Technical University "Kharkiv Polytechnic Institute", Ukraine, Kharkiv, 61002
}

\begin{abstract}
The methodological approaches to the use of genetic algorithm for the synthesis of the rational structure of the radar surveillance system are proposed in the paper. The structure of the radar surveillance system is presented in the form of an incidence matrix, which is used as a chromosome by the operators of the genetic algorithm. This matrix is used as a chromosome by the operators of the genetic algorithm. The elements of the incidence matrix that describe the relationships between the elements of the structure of the observation system are genes in the genetic algorithm. In each cycle of the genetic algorithm, a pair of chromosomes is paired, during which part of the genes are exchanged, which for the system under study means the appearance and disappearance of the corresponding connections between the elements. The calculation of the values of the efficiency of radar surveillance for each variant of the structure is proposed to be carried out using the ant colony optimization. The gain in the value of the conditional probability of correct detection with a fixed probability of false alarm is approximately $10 \%$
\end{abstract}

Keywords - genetic algorithm, artificial intelligence, optimization, route, radar surveillance system.

\section{INTRODUCTION}

Every year, the number of terrorist organizations in the world grows, their structure strengthens and, as a result, the terrorist threat to the civilian population spreads in many countries [1]. Today, the fight against terrorism is becoming a global international problem [2]. It requires coordination of efforts of different countries [3-4].

International terrorism has a special place in the complex problem of combating air terrorism. The events of September 11, 2001 caused a wide resonance in the world [5]. It has been suggested that the number of victims of a notorious terrorist act could be much smaller if the civilian aircraft seized by the terrorists were destroyed by US air defenses [6-7].
Following this tragedy, both the United States and other countries (for example, Ukraine) raised the issue of amending the legal framework. The amending the legal framework regarding the conditions (requirements) under which the destruction of civilian aircraft with passengers on board captured by terrorists was raised.

Today the danger of air terrorism in Eastern Europe is growing significantly. A large number of specialists from all over the world have been working on solving the issue of the use of weapons against aircraft seized by terrorists for many years. But there is still no unambiguous answer to this question [8]. As of today, the Air Force of the Armed Forces of Ukraine has the right to destroy almost any aircraft under certain legal circumstances [4, 9-11]. At the same time, terrorist organizations use unmanned aerial vehicles for their own purposes. Today, with the development of unmanned aerial vehicles (UAV), the range of their application is increasing. At present, UAVs are a rather serious problem. In fact, the most logical way to get rid of a drone is to destroy it, but before that it must be detected by radar [12-17]. Therefore, the creation of an effective airspace surveillance system is an important task today.

\section{Literature REVIEW AND PROBLEM STATEMENT}

Studies of the construction of radar surveillance of airspace are disclosed in [18, 19]. In [18] the modern methods of estimating the efficiency of the radar surveillance system of the airspace and the air defense system are systematized, the set of indicators and efficiency criteria is generalized. In [19] the theoretical bases of synthesis of adaptive structures of the system of antiaircraft missile and artillery cover are stated. But in the analyzed literature little attention is paid to the construction of a radar surveillance system (a component of the air defense system). 


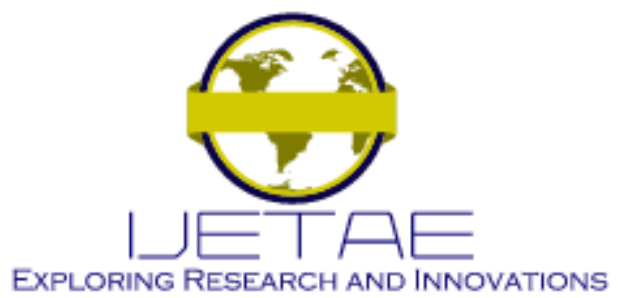

International Journal of Emerging Technology and Advanced Engineering

Website: www.ijetae.com (E-ISSN 2250-2459, Scopus Indexed, ISO 9001:2008 Certified Journal, Volume 11, Issue 08, August 2021)

In [20] methodical approaches to optimizing the spatial structure of the radar surveillance system are presented. The danger from aircraft from each direction is considered to be the same, which somewhat reduces the limits of application of the results obtained in [20].

In the general case, there are many options for actions of aircraft violating the rules of airspace use (or unmanned aerial vehicles used in illegal actions). Obviously, of all possible options, the violator will choose the most effective. The effectiveness of each option for violating the rules of airspace use, including the structure of the radar surveillance system. The elements of the radar surveillance system of airspace are exposed by the enemy before the start of illegal actions. It can be argued that the optimal structure of the radar surveillance system Sopt is a structure that provides minimum efficiency of the offending aircraft. The variant of application in the existing conditions of the situation (with the structure of the radar surveillance system of airspace $S_{\text {opt }}$ ) [20]:

$$
E\left(S_{\text {opt }}, Z\left(S_{\text {opt }}\right), P\right)=\min _{S \in \Omega} \max _{Z \in \Psi} E(S, Z(S), P),
$$

where $\Omega$ - many possible structures of the radar surveillance system of airspace;

$S \in \Omega$ - possible structure of the radar surveillance system of airspace;

$\Psi$ - many possible options for action of the aircraft violating the rules of use of airspace;

$\mathrm{Z}(\mathrm{S}) \in \psi-$ the variant of actions of the aircraft violating the rules of airspace use, defined for the structure $S$ of the radar surveillance system of airspace;

$\mathrm{P}$ - a set of other conditions;

$E(S, Z(S), P)$ - indicator of the effectiveness of radar surveillance of airspace (target function).

The application of known mathematical methods of classical optimization theory to determine the optimal structure of the radar surveillance system of airspace is impossible. It is primarily due to the complexity of the mathematical description of the expression for the efficiency indicator (1). The following methods can be used to determine $\mathrm{S}_{\text {opt }}$ :

- complete search [21];

- dynamic programming [22, 23];

- the genetic algorithms [24, 25];
- greedy algorithms, fast gradient method [26] and others [27-36].

A complete search [21] of all possible options is the simplest solution to this problem, the solution found is always optimal, but the time to solve the problem increases exponentially. In practice, the use of the search method is complicated due to the large number of possible variants of structures. The disadvantage of the method of dynamic programming is the mandatory linearity of the objective function $[22,23]$ and does not provide sufficient speed and does not work in non-stationary systems.

The disadvantage of the greedy algorithms, fast gradient method [26] is the choosing the step size and descent direction.

The main disadvantages of the discrete programming [27-29] are the next:

- the more complex the mathematical analysis as compared to continuous programming;

- the stability is degraded;

- the loss of information.

The main disadvantages of the discrete programming [30-36] are the next:

- to fall into local optimum in high-dimensional space;

-a low convergence rate in the iterative process.

\section{MAterials AND RESEARCH MEthodS}

The purpose of this article is to develop a method for building a system of radar surveillance of airspace based on a genetic algorithm [24-25]. The genetic algorithm, the use of which is proposed in the article, allows to find the optimal structure of the radar surveillance system taking into account the actions of the aircraft - violator of the rules of airspace use.

\section{Basic definitions.}

Radar surveillance system in the work means:

- a set of interconnected forces and means of radar surveillance;

- the control points and communication systems, which are united by a single purpose, deployed in a single order, with a single leadership of airspace surveillance.

The control point carries out data collection from radar means, their processing, if necessary delivery of the information on fire means. 


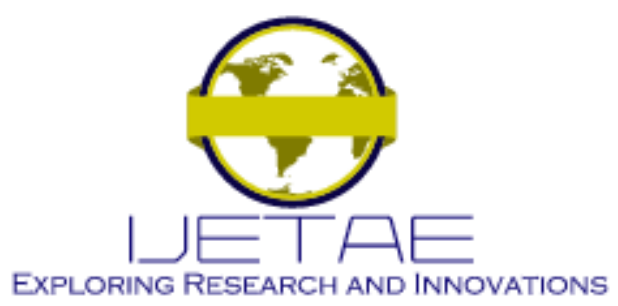

International Journal of Emerging Technology and Advanced Engineering

Website: www.ijetae.com (E-ISSN 2250-2459, Scopus Indexed, ISO 9001:2008 Certified Journal, Volume 11, Issue 08, August 2021)

The structure of the radar system of airspace surveillance is a set of elements of the surveillance subsystem (radar means, control points), as well as control and information links between the radar means and the control point (internal communications), as well as between the control point and fire means. (external relations) (Fig 1).

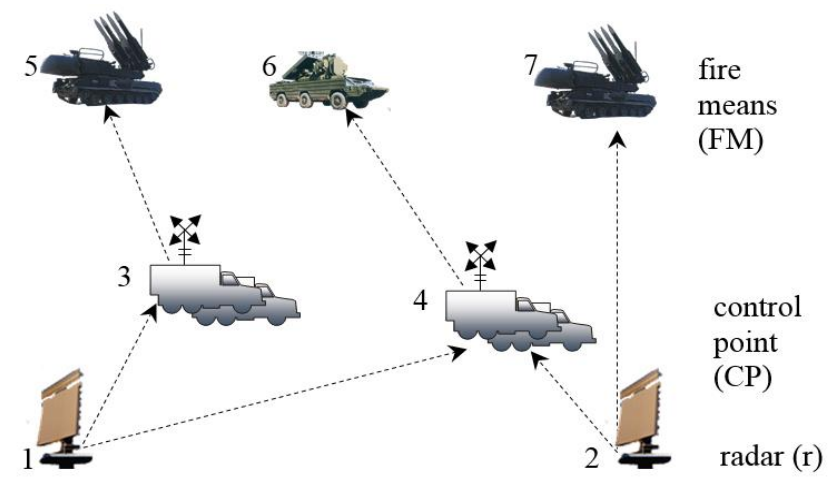

Fig. 1. An example of the structure of the radar surveillance system

Fig.1 shows a variant of the structure of the radar surveillance system of airspace, the elements of which are two means of radar $(1,2)$ and two control points $(3,4)$. For example, the main types or radars are P-18MA (Ukraine), P-18MU (Ukraine) [37-38].

The elements of the surveillance system are connected by connections (shown by dotted arrows) with each other and with three fire means $(5,6,7)$.

To compare the efficiency of observation systems, we introduce the dynamic programming method [22-23] in the following order:

- comparison according to indicator 1 - of several options for building an airspace surveillance system will be more effective one in which the means of destruction provided by intelligence information, provide a reliable cover of the objects of a certain list;

- comparison by indicator 2 - of several options for building an airspace surveillance system, for which the value of indicator 1 is the same, the one with the greater value of the mathematical expectation of the number of affected air objects will be more effective;

- comparison of indicator 3 - of several options for building an airspace surveillance system, for which the values of indicators 1 and 2 are the same, will be more effective one in which the greater the cost of resources by the aircraft.
For example, in determining the routes and flight profiles of an unmanned aerial vehicle, the violator will in some cases take into account the possibility of returning the aircraft to the aerodrome (landing site). Resulting in not all routes and flight profiles of the unmanned aerial vehicle from takeoff to reconnaissance (impact) and in the opposite direction will be acceptable. We will not enter a separate indicator that characterizes the acceptability of routes and flight profiles of the air object. We believe that ensuring the possibility of returning the air object to the take-off point is taken into account when calculating the efficiency indicator (1). It is also obvious that the option of the violator's actions, for the implementation of which he does not have enough resources, will be inadmissible.

As defined above, a possible way to find an effective system of radar surveillance of airspace is a pairwise comparison of possible options on indicators 1-3 using the dynamic programming method ordering. Thus for each variant of construction of system of radar supervision of airspace it is necessary to define set of possible variants of actions of the violating aircraft. Then for each pair "variant of construction of system of radar supervision of airspace a variant of application of the violating aircraft" to define values of indicators 1-3, and analyzing the value of indicators 1-3. Choose the best option for building a system of radar surveillance of airspace. In practice, the use of such an approach will be complicated due to the extremely large number of flight options of the offending aircraft. A large number of possible options for combat operations by the enemy excludes the possibility of using the method of search to assess the effectiveness of these options. The authors propose to use the method of recognizing the actions of the air intruder based on the ant colony optimization (ant algorithm) [39-41] to determine the flight routes.

2. The use of a genetic algorithm to build a system of radar surveillance of airspace.

\subsection{The essence of the genetic algorithm.}

The genetic algorithm is based on the idea of evolution by natural selection and is an artificial imitation of such properties of living nature as natural selection, adaptation to changing environmental conditions, heredity of the traits of parents and so on. 


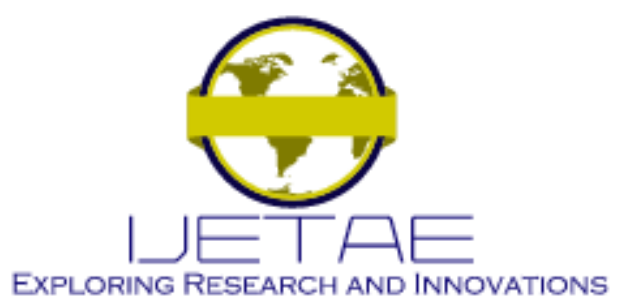

International Journal of Emerging Technology and Advanced Engineering

Website: www.ijetae.com (E-ISSN 2250-2459, Scopus Indexed, ISO 9001:2008 Certified Journal, Volume 11, Issue 08, August 2021)

The essence of genetic search is to cyclically replace one population with another, more adapted. We can assume that the entire population consists in time of discrete generations $\Omega^{(0)}, \Omega^{(1)}, \Omega^{(2)} \ldots, \Omega^{(T)}$. Generation $\Omega^{(t+1)}$ Is a set of individuals whose parents belong to a generation $\Omega^{(t)}$. Generation $\Omega^{(0)}$ is the initial population. The process of generation $\Omega^{(0)}$ is called initialization. Each subsequent generation is the result of the cycle of the genetic algorithm.

For each individual of the current generation, the value of the objective function is determined, which characterizes the adaptability of the individual. In the course of selection (selection) the least adapted individuals die, and the most adapted get the opportunity to reproduce offspring during pair crossing. This leads to the emergence of new individuals who inherit some traits from their parents. Thus, from generation to generation, good properties are spread throughout the population. To increase the diversity of search and a more complete study of the search space, a mutation is used - the introduction of new individuals into the population. Eventually, the population will match to the most adapted individual (to the optimal solution).

To use the properties of individuals in a genetic algorithm, these properties are presented in encoded form in the form of a chromosome. A chromosome is a set of genes, each of which retains a certain property (trait, characteristic) of the individual. Depending on what properties need to be encoded and, accordingly, what values can take genes, there are binary, numerical and vector chromosomes, and depending on the structure of the search space chromosomes can be one-, two- or multidimensional. Thus, genetic operators (crossing, mutations, selection) carry out the transformation of chromosomes without using information about the internal structure of the object of study.

\subsection{Representation of the structure of the radar surveillance system of airspace in the form of a chromosome.}

When using a genetic algorithm to build an optimal airspace radar surveillance system, it is necessary to represent this structure in the form of a chromosome, which is essentially a mathematical model of an information system displaying its elements and the essential relationships between them.
It is known $[18,19]$ that sufficiently adequate to solve the problem of studying the structure of the information system, which is a radar surveillance system, is a mathematical model, which is represented as an incidence matrix in which row numbers correspond to information source numbers and column numbers - consumer numbers information The elements $a_{i j}$ at the intersection of rows and columns become the characteristics of the information link that connects the corresponding source of information with the corresponding consumer: (note that the same elements of the structure can be both sources and consumers of information).

Numerical calculations also require the use of a variety of incidence matrix - orthonormal incidence matrix, in which the values of the elements can become 0 or 1 . An incidence matrix is a logical matrix that shows the relationship between two classes of objects. Such a matrix can be used if the study is necessary to determine the presence of information links between the relevant elements of the structure systems without determining the characteristics of the connection.

$$
\begin{aligned}
& \text { consumer information } \\
& S=\left(\begin{array}{cc|ccccc} 
& & 1 & 2 & 3 & \ldots & J \\
\cline { 2 - 6 } \text { sources } & 2 & a_{11} & a_{12} & a_{13} & \ldots & a_{1 J} \\
\ldots & a_{21} & a_{22} & a_{23} & \ldots & a_{2 J} \\
& \ldots & \ldots & \ldots & \ldots & \ldots \\
& I & a_{I 1} & a_{I 2} & a_{I 3} & \ldots & a_{I J}
\end{array}\right) .
\end{aligned}
$$

An example of an orthonormal incidence matrix for the structure of the radar surveillance system of airspace, shown in Fig. 1, has the form:

$$
S=\left(\begin{array}{r|ccccc}
\multicolumn{8}{c}{\text { consumerinformation }} \\
\cline { 2 - 6 } \text { sources } & 3 & 4 & 5 & 6 & 7 \\
\hline 1 & 1 & 1 & 0 & 0 & 0 \\
3 & 0 & 1 & 0 & 0 & 1 \\
4 & 0 & 0 & 1 & 0 & 0 \\
& 0 & 0 & 0 & 1 & 0
\end{array}\right)
$$

It is easy to see the analogy between the mapping of the radar surveillance system of airspace in the matrix of the form (2) and the mapping of the point of the solution space in the two-dimensional chromosome, which takes place in the genetic algorithm. 


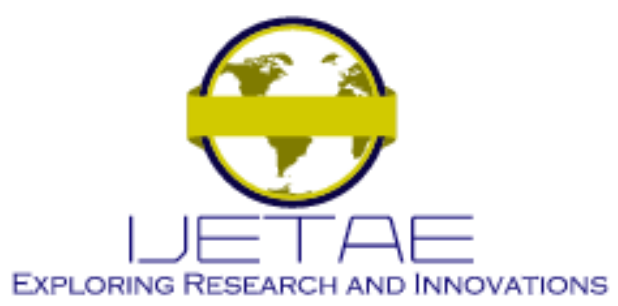

International Journal of Emerging Technology and Advanced Engineering

Website: www.ijetae.com (E-ISSN 2250-2459, Scopus Indexed, ISO 9001:2008 Certified Journal, Volume 11, Issue 08, August 2021)

The orthonormal incidence matrix (2) is a twodimensional chromosome and can be used to represent the structure of the observation system in a genetic algorithm. Developing the above analogy, we call the elements of the matrix (2) genes, and several implementations of the matrix (2) with different values of the elements (genes) - a set of chromosomes, or population. Note that in the general case, the structure of the chromosome may be different. This will be determined by the content of the problem to be solved. Numerical chromosomes must be used to determine the numerical value of the relationship between the elements of the structure, but if the value of several relationship characteristics is determined, a vector chromosome must be used.

Fig. 2 shows the method of genetic search for the optimal structure of the radar surveillance system of airspace.

Let's explain the work of individual components of the methodology in more detail.

\subsection{Initialization of the initial population.}

When initializing the initial population $\Omega^{b(0)}$, chromosomes are randomly $N_{b}$ created - matrices of the species (2). It is necessary to take into account the limitations on the form of matrices (2), which will be determined by the nature of the problem to be solved, for example:

- the fire means receives information from only one control point - this means that the corresponding columns of the matrix can be only one unit, the other elements of the columns - zeros;

- the radar surveillance tool provides intelligence to only one control point - this means that the corresponding rows of the matrix can be only one unit, the other elements of the rows - zeros;

- the control point may receive and process intelligence data from no more than $N_{r \text { max }}$ surveillance means and provide information to no more than $N_{F M \text { max }}$ fire means.

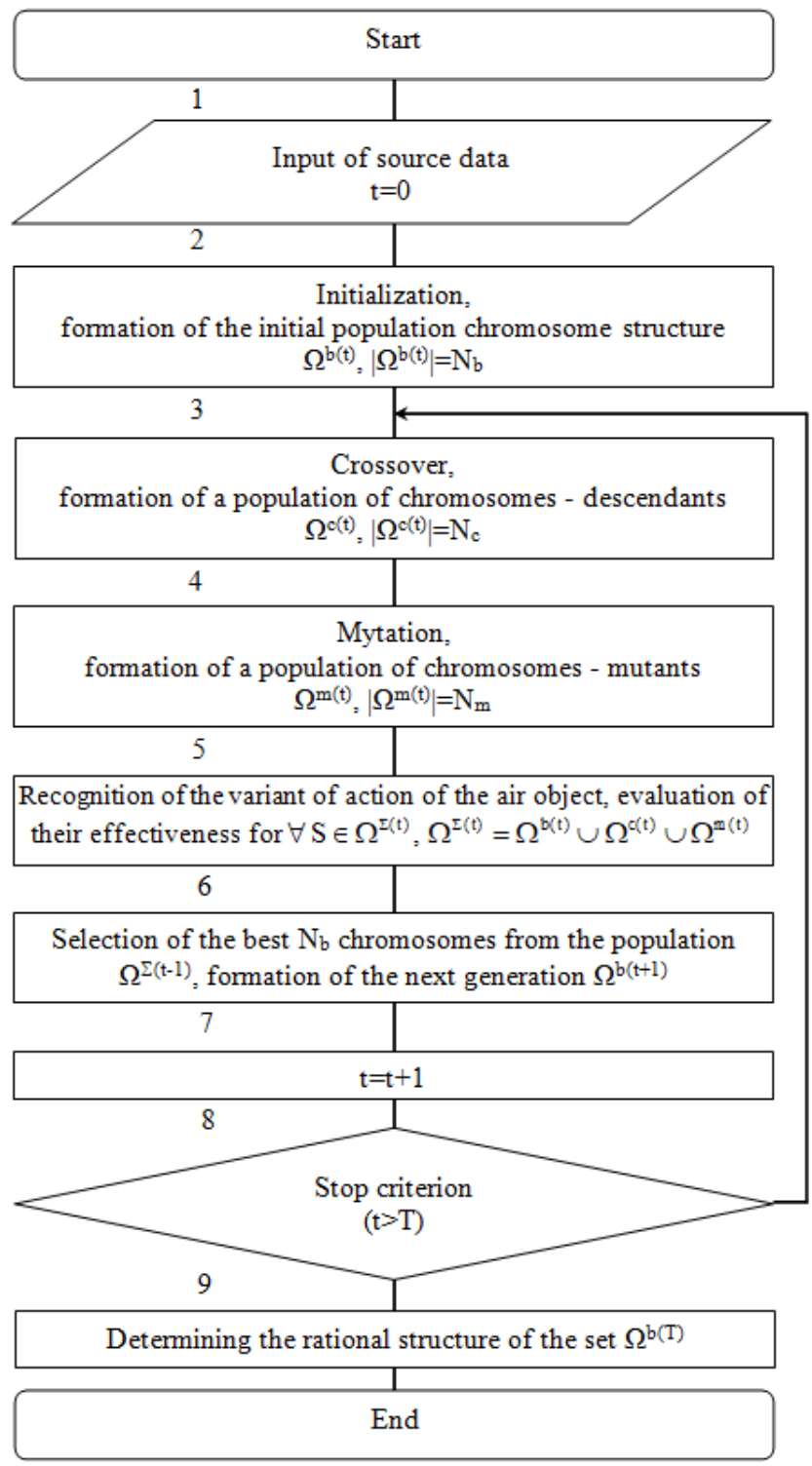

Fig. 2. Scheme of genetic algorithm in determining the rational structure of the radar surveillance system 


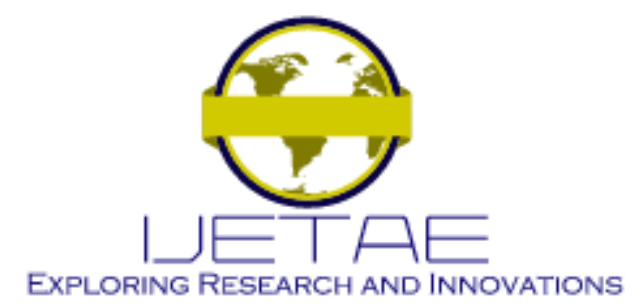

International Journal of Emerging Technology and Advanced Engineering

Website: www.ijetae.com (E-ISSN 2250-2459, Scopus Indexed, ISO 9001:2008 Certified Journal, Volume 11, Issue 08, August 2021)

\subsection{Application of crossing and mutation operators.}

When crossing the chromosomes of the current population $\Omega^{b(t)}$ are randomly divided into pairs. The crossing operator exchanges the chromosome genes of each pair. As a result, a population of $\Omega^{c(t)}$ chromosomesdescendants with the number $N_{c}$ is formed.

Crossing should be performed taking into account the constraints on the appearance of the matrix (2), so as not to result in chromosomes, the corresponding structures of which cannot be created. In the example below (Figure 3), a block crossover operator for two-dimensional chromosomes is used. When crossing a chromosome, genes are exchanged located in a region whose position is determined randomly, taking into account the above restrictions.

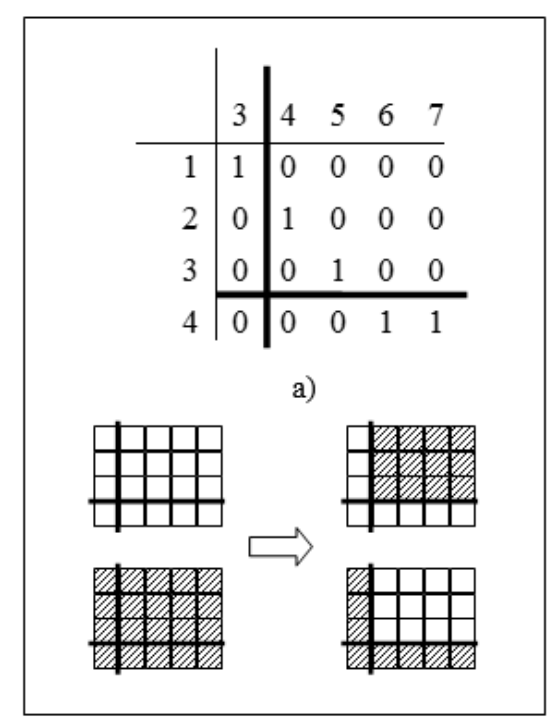

Fig. 3. Block crossing operator

a) determination of the site of gene exchange of two-dimensional chromosomes;

b) an example of the operator's application

Chromosome-type constraints should also be considered when using a mutation operator to replace one or more chromosome genes randomly selected from a set with the opposite value, which means creating or removing links between its elements in the structure of the observation system under study. As a result, a population of mutant chromosomes $\Omega^{m(t)}$ is formed in each cycle of the genetic algorithm.
2.5 Recognition of the variant of action of the air violator and evaluation of the effectiveness of combat operations in the structure of the radar surveillance system $S \in \Omega^{\sum(t)}$, where $\Omega^{\Sigma(t)}=\Omega^{b(t)} \cup \Omega^{c(t)} \cup \Omega^{m(t)}$, is carried out using the ant colony optimization [39-41] proposed by the authors. At each $\mathrm{T}$ cycle of the genetic algorithm for each chromosome $S$ of the set $\Omega^{\Sigma(t)}$, the variant of the violator's actions is recognized and its efficiency is evaluated. The next step in the cycle of the genetic algorithm is the selection of the best $N_{b}$ chromosomes from the population $\Omega^{\Sigma(t)}$ by the value of the objective function (1). The resulting chromosomes form a new population of $\Omega^{b(t+1)}$, which is the starting point for the next cycle of the genetic algorithm. After performing $T$ cycles, the genetic algorithm stops working. Analysis of the values of the objective function (1) for the obtained set of $\Omega^{(T)}$ chromosomes allows to determine one or more rational structures of the radar system of airspace observation.

Let's compare the method of radar observation system construction of the airspace on the basis of genetic algorithm and dynamic programming method. As an indicator of efficiency, we will choose the conditional probability of correct detection of an airborne object. We fix the conditional probability of a false alarm at the level of $10^{-2}$.

The value of conditional probability of correct detection of an airborne object by the method on the basis of genetic algorithm is 0,9076 .

The value of conditional probability of correct detection of an airborne object by the dynamic programming method is 0,8235 .

The gain in the value of the conditional probability of correct detection with a fixed probability of false alarm is approximately $10 \%$.

\section{CONCLUSIONS}

Thus, the article proposes a method of building a radar surveillance system based on a genetic algorithm. The structure of the observation system is represented as a twodimensional incidence matrix. This matrix is used as a chromosome by the operators of the genetic algorithm. The elements of the incidence matrix that describe the relationships between the elements of the structure of the observation system are genes in the genetic algorithm. 


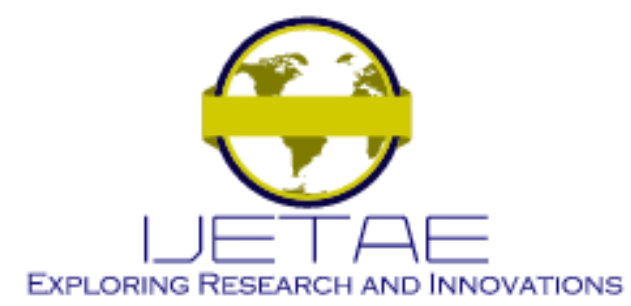

International Journal of Emerging Technology and Advanced Engineering Website: www.ijetae.com (E-ISSN 2250-2459, Scopus Indexed, ISO 9001:2008 Certified Journal, Volume 11, Issue 08, August 2021)

In each cycle of the genetic algorithm, a pair of chromosomes is paired, during which part of the genes are exchanged, which for the system under study means the appearance and disappearance of the corresponding connections between the elements. The calculation of the values of the target function (combat effectiveness) is proposed to be carried out using the ant algorithm, and for each chromosome of the current population, the variant of the aircraft violating the rules of airspace use is first recognized. The gain in the value of the conditional probability of correct detection with a fixed probability of false alarm is approximately $10 \%$

Further research can be aimed at developing a method for synthesizing the optimal structure of the radar surveillance system to determine the composition of the elements of the system and their location on the ground.

\section{REFERENCES}

[1] Medov, M. Terrorism in the Russian Federation and Western Europe: Main Causes and Conditions of Spread. Russian investigator, 2012, №20, pp. 30-33.

[2] Bartasiuk, A., Kontsevyk, K. On the issue of regulating the system of countering terrorism and extremism: analysis of foreign experience. Scholarly notes PSU, 2013, T. 4, №4, pp.548-557. Available from: 〈http://pnu.edu.ru/media/ejournal/articles/2013/TGU_4_125.pdf>.

[3] Zonov, F. International terrorism and world experience in combating it. Power, 2011, №12, pp. 103-106. Available from: $<$ https://cyberleninka.ru/article/v/mezhdunarodnyy-terrorizm-imirovoy-opyt-borby-s-nim>.

[4] Skrynnykova, N. Foreign experience in the fight against terrorism: countermeasures. Scientific list of Uzhgorod National University, 2014, vol. 28, T.3. pp.37-40.

[5] Krasnov, A., Bessarabov, N. Some approaches to the problem of countering air terrorism in the United States. Foreign military review. 2008, №11, pp. 21-26.

[6] Kaminskiy, V. V. The fight against air terrorism must begin on the ground. Science and technology of the Air Force of the Armed Forces of Ukraine, 2014, №1 (14). pp.16-23. Available from: < http://www.hups.mil.gov.ua/periodic-app/article/567/eng>.

[7] Hladenko, V. Problems of understanding modern terrorism. Scientific works of Nikolaev State University named after V.O. Sukhomlinsky, 2005, vol. 27, T.40, pp. 156-159.

[8] Bradshaw, R. Hijacked planes and the doctrine of necessity. The student journal of law Available from: <https://sites.google.com/site/349924e 64e68f035/issue-6/hijackedplanes-and-the-doctrine-of-necessity>.

[9] Resolution of the Cabinet of Ministers of Ukraine № 153 “About the statement of the Order of interaction on the termination of illegal actions of the aircraft which can be used for commission of terrorist acts in airspace of Ukraine in peacetime" of February 7, 2007. Available from: <http://zakon2.rada.gov.ua/laws/show/153-2007-п>.
[10] Resolution of the Cabinet of Ministers of Ukraine № 377 “About the statement of the order of performance of tasks by the next forces on air defense of Armed forces in peacetime" of May 26, 2005. Available from: <http://zakon2.rada.gov.ua/laws/show/3772005-п >.

[11] Resolution of the Cabinet of Ministers of Ukraine № 401 "On approval of the Regulations on the use of airspace of Ukraine" of December 6, 2017. Available from: <https://zakon.rada.gov.ua/laws/show/954-2017-\%D0\%BF\#Text >.

[12] I. Ruban, H. Khudov, V. Lishchenko, A. Zvonko, S. Glukhov, I. Khizhnyak, V. Maliuha, Y. Polonskyi, R. Kushpeta, The Calculating Effectiveness Increasing of Detecting Air Objects by Combining Surveillance Radars into The Coherent System, International Journal of Emerging Trends in Engineering Research, $\begin{array}{llll}\text { Vol. 8., № 4, 2020, } & \text { pp. 1295-1301. } & \text { DOI: }\end{array}$ https://doi.org/10.30534/ijeter/2020/58842020.

[13] H. Khudov, I. Khizhnyak, I. Yuzova, O. Baranik, G. Semiv, S. Bondarenko, and O. Tytarenko. The Optimization Technique for Joint Discrete Search and Detection of Observation Objects, International Journal of Emerging Trends in Engineering Research, № $8(2), \quad 2020, \quad$ pp. 533-538. DOI: https://doi.org/10.30534/ijeter/2020/42822020.

[14] V. Lishchenko, V. Chaliy, H. Khudov, and A. Zvonko. Proposals for Improving of Air Surveillance Informativity in MIMO Radar Systems Based on Two-Dimensional Radars, in Intern. Scient.-Pract. Conf. Problems of Infocommunications. Science and Technology (PIC S\&T), 2018, pp. 153-156. DOI: https://doi.org/10.1109/infocommst.2018.8632052.

[15] H. Khudov, A. Zvonko, I. Khizhnyak, V. Shulezko, V. Khlopiachyi, V. Chepurnyi, and I. Yuzova. The Synthesis of the Optimal Decision Rule for Detecting an Object in a Joint Search and Detection of Objects by the Criterion of Maximum Likelihood, International Journal of Emerging Trends in Engineering Research, № 8(2), 2020, pp. 520-524. DOI: https://doi.org/10.30534/ijeter/2020/40822020.

[16] V. Lishchenko, H. Khudov, V. Tiutiunnyk, V. Kuprii, F. Zots, and G. Misiyuk The Method of Increasing the Detection Range of Unmanned Aerial Vehicles In Multiradar Systems Based on Surveillance Radars, in 2019 IEEE 39th International Conference on Electronics and Nanotechnology (ELNANO), 2019. P. 559-562. DOI: https://doi.org/10.1109/ELNANO.2019.8783263.

[17] V. Lishchenko, H. Khudov, B. Lisogorsky, O. Baranik, D. Holovniak, and O. Serdjuk The MIMO System on Based Existing Mechanical Rotation Radars with Wide Surveillance Area, in 2020 IEEE 40th International Conference on Electronics and Nanotechnology (ELNANO), 2020. P. 625-628. DOI: https://doi.org/10.1109/ELNANO.50318.2020.90887463.

[18] Retrieved from https://www.rand.org/topics/air-defense.html.

[19] Zbroyna borot'ba u povitri ta kosmosi [Tekst] : pidruchnyk / [M. O. Yermoshyn ta in.] ; za zah. red. M. O. Yermoshyna ; Kharkiv. nats. un-t Povitr. Syl im. Ivana Kozheduba. - Kharkiv : KHNUPS, 2019. 491 s. : rys., tabl. - Bibliohr.: s. 491. - 100 prym. - ISBN 978-966468-088-9 


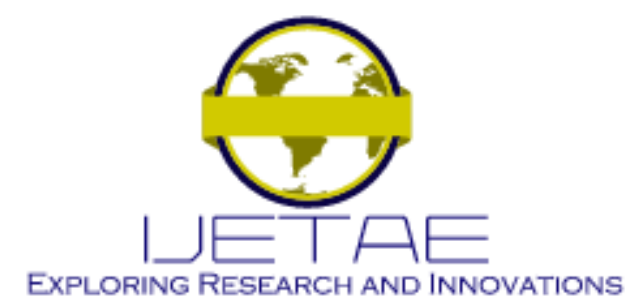

International Journal of Emerging Technology and Advanced Engineering Website: www.ijetae.com (E-ISSN 2250-2459, Scopus Indexed, ISO 9001:2008 Certified Journal, Volume 11, Issue 08, August 2021)

[20] Teoretychni osnovy pobudovy ta zastosuvannya rozviduval'noupravlyayuchykh informatsiynykh system protypovitryanoyi oborony [Tekst] : monohrafiya / S. P. Yarosh ; za red I. O. Kyrychenka ; Kharkiv. un-t povitr. syl im. Ivana Kozheduba. Kharkiv : KHUPS, 2012. - 511 s. : rys., tabl. - Bibliohr.: s. 500-511. - 300 prym. - ISBN 978-966-468-066-7

[21] Raigorodsky, A. Extreme problems of graph theory and the Internet: Moscow, 2012. 104 p.

[22] G. V. Khudov, Features of optimization of two-alternative decisions by joint search and detection of objects. Problemy Upravleniya I Informatiki (Avtomatika), 2003, № 5, pp. 51-59.

[23] Nygard, K.E., Chandler, P.R., and Pachter, M. Dynamic network flow optimization models for air vehicle resource allocation. In: Proc. of the the American Control Conference, Arlington, Texas, 2001. pp. 1853-1858.

[24] Urubkov, A.R. and Fedotov, I.V. Methods and models of optimization of management decisions: Moscow, 2011. 240 p.

[25] Darrah, M., Niland, W. and Stolarik, B. UAV cooperative task assignments for a SEAD mission using genetic algorithms. In: AIAA Guidance, Navigation, and Control Conference and Exhibit, AIAA2006-6456. Keystone, Colorado, 2006.

[26] Gutina, G., Yeob, A., and Zverovicha, A. Traveling salesman should not be greedy: domination analysis of greedy-type heuristics for the TSP. Discrete Applied Mathematics, 2002, no.117, p. 81-86.

[27] Sigal, I. and Ivanova, A. Introduction to applied discrete programming: models and computational algorithms: Moscow, 2003.240p.

[28] Makarov, I.M., Lokhin, V.M. and Manko, S.V. Intelligent control systems for unmanned aerial veicles based on the integrated application of fuzzy logic technologies and associative memory. Aerospace instrumentation, 2002. no. 2. p. 29-36.

[29] Moiseev, V.S. Applied theory of control of unmanned aerial vehicles: Kazan, 2013.768 p.

[30] Norseev, S.A. Algorithms for pre-flight quasi-optimal determination of routes for a group of unmanned aerial vehicles (Kovrov) [Research Report], 2016.182 p.

[31] I. Ruban, V. Khudov, O. Makoveichuk, H. Khudov, and I. Khizhnyak. A Swarm Method for Segmentation of Images Obtained from On-Board Optoelectronic Surveillance Systems, in Intern. Scient.-Pract. Conf. Problems of Infocommunications. Science and Technology (PIC S\&T), 2018, pp. 613-618. DOI: https://doi.org/10.1109/infocommst.2018.8632045.

[32] I. Ruban, H. Khudov, O. Makoveichuk, M. Chomik, V. Khudov, I. Khizhnyak, V. Podlipaiev, Y. Sheviakov, O. Baranik, and A. Irkha. Construction of methods for determining the contours of objects on tonal aerospace images based on the ant algorithms, EasternEuropean Journal of Enterprise Technologies, № 5/9 (101), 2019, pp. 25-34. https://doi.org/10.15587/1729-4061.2019.177817.
[33] I. Ruban, H. Khudov, O. Makoveichuk, I. Khizhnyak, V. Khudov, V. Podlipaiev, V. Shumeiko, O. Atrasevych, A. Nikitin, and R. Khudov. Segmentation of opticalelectronic images from on-board systems of remote sensing of the Earth by the artificial bee colony method, Eastern-European Journal of Enterprise Technologies, № 2/9 (98), 2019, pp. 37-45. DOI: https://doi.org/10.15587/17294061.2019.161860.

[34] I. Ruban, V. Khudov, H. Khudov, and I. Khizhnyak An Improved Method for Segmentation of a Multiscale Sequence of Optoelectronic Images, in Intern. Scient.-Pract. Conf. Problems of Infocommunications. Science and Technology (PIC S\&T), 2017, pp. 137-140.

DOI: https://doi.org/10.1109/INFOCOMMST.2017.8246367.

[35] I. Ruban, O. Makoveichuk, V. Khudov, I. Khizhnyak, H. Khudov, I. Yuzova, and Y. Drob. The Method for Selecting the Urban Infrastructure Objects Contours, in Intern. Scient.-Pract. Conf. Problems of Infocommunications. Science and Technology (PIC S\&T), 2019, pp. 689-693. DOI: https://doi.org/10.1109/infocommst.2018.8632045.

[36] H. Khudov, O. Makoveychuk, I. Khizhnyak, I. Yuzova , A. Irkha, and V. Khudov. The Mosaic Sustainable Marker Model for Augmented Reality Systems, IJATCSE, № 9(1), 2020, pp. 637-642. DOI: https://doi.org/10.30534/ijatcse/2020/89912020.

[37] Retrieved from http://ust.com.ua/ru/item/rls-malaxit .

[38] Retrieved from https://www.aerotechnica.ua/nazemnayapodvizhnaya-radiolokaczionnaya-stancziya-p-18ma.html.

[39] H. Khudov, I. Ruban, O. Makoveichuk, H. Pevtsov, V. Khudov, I. Khizhnyak, S. Fryz, V. Podlipaiev, Y. Polonskyi, and R. Khudov. Development of methods for determining the contours of objects for a complex structured color image based on the ant colony optimization algorithm, Eureka: Physics and Engineering, № 1, 2020, pp. 34-47. DOI: https://doi.org/10.21303/2461 4262.2020.001108.

[40] I. Ruban, H. Khudov, O. Makoveichuk, M. Chomik, V. Khudov, I. Khizhnyak, V. Podlipaiev, Y. Sheviakov, O. Baranik, and A. Irkha. Construction of methods for determining the contours of objects on tonal aerospace images based on the ant algorithms, EasternEuropean Journal of Enterprise Technologies, № 5/9 (101), 2019, pp. 25-34. https://doi.org/10.15587/1729-4061.2019.177817.

[41] I. Ruban, H. Khudov, V. Khudov, I. Khizhnyak, and O. Makoveichuk. Segmentation of the images obtained from onboard optoelectronic surveillance systems by the evolutionary method, Eastern-European Journal of Enterprise Technologies, № 5/9 (89), 2017, pp. 49-57. DOI: https://doi.org/10.15587/17294061.2017.109904. 